\title{
Design of an ecologically-based IPM program for fruit flies (Diptera: Tephritidae) in Tanzania
}

\author{
Maulid W. Mwatawala ${ }^{1}$, Marc De MeYer ${ }^{2 *}$, Rhodes H. MAKUndi ${ }^{3}$, Amon P. MAerere ${ }^{1}$
}

${ }^{1}$ Dep. Crop Sci. Prod., Sokoine Univ. Agric., Morogoro, Tanzania

2 Entomol. Sect., R. Mus. Cent. Afr., Tervuren, Belgium marc.de.meyer@africamuseum.be

${ }^{3}$ Pest Manag. Cent., Sokoine Univ. Agric., Morogoro, Tanzania

\section{${ }^{*}$ Correspondence and reprints}

Received 24 February 2008 Accepted 15 September 2008

Fruits, 2009, vol. 64, p. 83-90 (C) 2009 Cirad/EDP Sciences All rights reserved DOI: $10.1051 /$ fruits/2009003 www.fruits-journal.org RESUMEN ESPAÑOL, p. 90

\section{Design of an ecologically-based IPM program for fruit flies (Diptera: Tephritidae) in Tanzania.}

Abstract - Introduction. Studies to determine the pre-requisites for formulating an IPM program for fruit flies (Diptera: Tephritidae) were conducted in the Morogoro region, Central Tanzania, from 2004 to 2006. Specifically, studies aimed at determining the biodiversity of fruit flies, and their incidence and abundance in the surveyed region. Materials and methods. Adult flies were collected using McPhail traps baited with parapheromones (methyl eugenol, trimedlure and cue lure) and synthetic food baits (hydrolyzed yeast and three-component lure). Flies were also collected from infested fruits after incubation in the laboratory. A total of four sites and neighboring areas representing the three agro-ecological zones of Morogoro region were used. Results. Two key fruit fly pests were determined based on incidence in major fruits and their seasonal abundance. The invasive fruit fly, Bactrocera invadens Drew, Tsuruta and White, is the key pest in the low and medium altitude areas. On the other hand, the Natal fruit fly, Ceratitis rosa Karsch, is the key frugivorous pest in the high altitude areas. Discussion. Management programs of fruit flies need to focus on key pests, taking into consideration their breeding in the non-agricultural habitats. Components of such a program should include the Male Annihilation Technique (MAT), legislation, use of parapheromones and baits, farm hygiene and sanitation, quarantine, surveillance and postharvest treatment.

Tanzania / tropical fruits / insect control / fruit flies / Bactrocera invadens / Ceratitis rosa / identification / pest surveys

Conception d'un programme écologique, basé sur une lutte intégrée contre les parasites, pour contrôler les mouches des fruits (Diptera : Tephritidae) en Tanzanie.

Résumé - Introduction. Des études visant à définir les préalables à la formulation d'un programme de lutte intégrée contre les mouches des fruits (Diptera : Tephritidae) ont été conduites dans la région de Morogoro, en Tanzanie centrale, de 2004 à 2006. Des études spécifiques ont cherché à déterminer la biodiversité existant parmi les populations de mouches des fruits, leur incidence et leur abondance dans la région prospectée. Matériel et méthodes. Des mouches adultes ont été collectées en utilisant des pièges McPhail amorcés avec des paraphéromones (eugénol méthylique, trimedlure et cue-lure) et des appâts synthétiques (levure hydrolysée et leurre à trois composants). Des mouches ont été également récupérées à partir de fruits infestés incubés en laboratoire. Quatre localités et leurs régions avoisinantes, représentant trois zones agro-écologiques de la région de Morogoro, ont été utilisées. Résultats. Deux espèces majeures de mouches des fruits ont été déterminées en se basant sur leur incidence sur les principaux fruits et sur leur abondance saisonnière. La mouche des fruits invasive, Bactrocera invadens Drew, Tsuruta and White, est le principal parasite trouvé dans les secteurs de basse et moyenne altitude. Par ailleurs, la mouche du Natal, Ceratitis rosa Karsch, est le principal parasite frugivore dans les secteurs de haute altitude. Discussion. Un programme de gestion des mouches des fruits devrait se concentrer sur les principaux parasites identifiés en prenant en considération leur multiplication dans les habitats non-agricoles. Les volets d'un tel programme devraient inclure la technique de stérilisation des mâles (MAT), la législation, l'utilisation de paraphéromones et d'appâts, les mesures sanitaires agricoles, la quarantaine, la surveillance et les traitements après récolte.

Tanzanie / fruits tropicaux / lutte anti-insecte / mouche des fruits / Bactrocera invadens / Ceratitis rosa / identification / enquête organismes nuisibles 


\section{Introduction}

The management of fruit fly pests is a major problem throughout the world [1]. Various methods for managing the flies have been tested and reported [1]. Previously, in the past, fruit fly eradication relied upon insecticides. However, broad-spectrum insecticides in cover sprays are known to create ecological, toxicological and environmental problems [2]. Evolving insect resistance to insecticides, public concern and increasingly restrictive environmental regulations have nearly precluded the use of aerial broadcasts [3]. Insecticides are also expensive and cannot be affordable to smallholder farmers. An appropriate approach for the latter group is, therefore, Integrated Pest Management (IPM). Knowledge of pest ecology and natural enemies as well as knowledge of socio-economic factors is essential in formulating an IPM program [4]. Studies on different ecological aspects of fruit flies were undertaken in central Tanzania to establish the parameters necessary for formulating an IPM program. Our paper proposes the components of such a program in the context of the Tanzanian farmer's environment.

\section{Materials and methods}

\subsection{Study sites}

Studies to determine the pre-requisites for formulating an IPM program of fruit flies were conducted for two years starting in October 2004 in the Morogoro Region, central Tanzania. Four sites (SUA, Mikese, Nyandira and Mkindo), located within the three agro-ecological zones of the region, were selected [5].

\subsection{Biodiversity of fruit flies}

The study of the fruit fly fauna was undertaken in a period of two years and involved trapping and sampling of fruits from all four sites and surrounding areas. Modified McPhail traps (AgriSense, UK) were used.
They were baited with five types of attractants: trimedlure, methyl eugenol, cue lure, hydrolyzed yeast and a three-component lure. An insecticide strip, dichlorovos (vapona), was placed in each trap to kill the adult flies. A protein bait was used to attract both sexes of different fruit fly species.

Trapping followed guidelines given by the International Atomic Energy Agency and the FAO [6]. The data were collected every week at the SUA site, where all attractants were changed after four weeks except the protein bait, which was changed every week. At the other sites, data were collected once every four weeks. At these sites, all attractants were placed and left in the field for one week in every four weeks. The fruits were collected each week, following previously established procedures [7]. The general methods of rearing the flies followed the protocols established by AFFI [8]. The adults were then killed by placing vials in a freezer for $4 \mathrm{~h}$. Specimens were preserved following White and Elson-Harris' methods [1]. The identification of flies was done using standard keys [1, 9, 10]. Fruit fly biodiversity of the different sites was determined using the Morisita-Horn (quantitative) index [11].

\subsection{Abundance of major fruit fly pests}

Abundance of fruit flies was determined under the setup previously described. Similarly, the efficacy of lures was compared in a split-split-plot design experiment at the SUA Horticulture Unit from January 2005 to January 2006. This one-year cycle was first divided into specific periods of observation of four weeks, coinciding with the time of changing the attractants. Thirteen periods of observation were scheduled. There were three sources of variation: periods of observation (main plot), lures (sub-plots) and orchards (sub-sub-plots). Each treatment was replicated twice. Methyl eugenol was tested against the synthetic food baits for efficacy in attracting Bactrocera invadens. Trimedlure was tested against synthetic food baits for efficacy in attracting Ceratitis rosa. The three-component lure was tested against protein bait for efficacy in attracting all the three major fruit fly species (after 
Table I.

List of fruit flies recorded from various fruits sampled from four study sites and elsewhere in Morogoro (Tanzania).

\begin{tabular}{lccc}
\hline Genus & Species & Total & Percentage \\
\hline Bactrocera & cucurbitae & 1350 & 3.16 \\
& invadens & 35326 & 82.76 \\
& latifrons & 209 & 0.49 \\
Capparimyia & melanaspis & 494 & 1.16 \\
Ceratitis & rosa & 1059 & 2.48 \\
& cosyra & 2828 & 6.63 \\
capitata & 235 & 0.55 \\
Dacus & bivittatus & 34 & 0.08 \\
& punctatifrons & 5 & 0.01 \\
Tririthrum & ciliatus & 1126 & 2.64 \\
& coffeae & 20 & 0.05
\end{tabular}

pooling catches). In all three cases, cue lure was used as a control, since it does not attract any of the species concerned. The weekly catches of the three major species by each of the synthetic food baits (protein bait and the three-component lure) were compared at SUA Horticulture Unit from January 2005 to January 2006. The sources of variation were times of observation (main plots), fruit fly species (sub-plots), and orchards (sub-sub-plots).

\subsection{Incidence and infestation rates of the major fruit fly pests}

The infestation rates of the major fruit fly pests were determined under the setup previously described. The incidence of each of the major fruit fly species was determined as the ratio of positive to the total number of samples of a fruit species. The analysis of variance (ANOVA) followed by means separation by Least Significance Difference (LSD) were used to compare the infestation rates of fruit flies in different fruit varieties. The chi-square goodness of fit test was used to determine the differences between the number of positive and negative samples in selected fruit species.

\section{Results}

\subsection{Biodiversity of fruit flies}

Among the three agro-ecological zones of the Morogoro region studied, a total of 11 fruit fly species belonging to five genera emerged from one or more of the 37 infested fruit species that were collected (table I). The highest number of emerged flies belongs to Bactrocera invadens followed by Ceratitis cosyra, B. cucurbitae and C. rosa. All the species that emerged from fruits were also recorded by trapping [5], except Capparimyia melanaspis, which was only recorded from Maerua sp., but was never caught in any trap. This record of $C$. melanaspis brings the total number of fruit fly species recorded by both trapping [5] and sampling fruits (table I) to 25. B. invadens was the dominant species, with more than $82 \%$ of flies collected from sampled fruits (table I), while more than $97 \%$ of flies were recorded from traps [5]. The between-sites abundance of fruit flies was determined by Morisita-Horn index (table II). A high similarity was observed between sites located in the low to medium altitude (SUA, Mikese and Mkindo) where 
Table II.

Diversity of fruit flies at four study sites of the Morogoro region (SUA, Mikese, Nyandira and Mkindo), central Tanzania, measured by the Morisita-Horn index (ratio).

\begin{tabular}{lccc} 
Study site & \multicolumn{3}{c}{ Study sites } \\
& Mkindo & SUA & Nyandira \\
\hline Mikese & 0.913 & 0.955 & 0.029 \\
Mkindo & - & 0.780 & 0.004 \\
SUA & - & - & 0.150
\end{tabular}

Table III.

Comparison of mean weekly catches of fruit flies by synthetic food baits in the Morogoro region, central Tanzania.

\begin{tabular}{lcc}
\hline Fruit fly species & \multicolumn{2}{c}{ Mean number of flies per trap per week } \\
\cline { 2 - 3 } & Protein bait & Three-component lure \\
\hline Bactrocera invadens & $7.1394 \mathrm{a}$ & $0.3317 \mathrm{~b}$ \\
Ceratitis rosa & $3.6442 \mathrm{~b}$ & $1.9038 \mathrm{a}$ \\
Ceratitis cosyra & $0.3702 \mathrm{c}$ & $0.0192 \mathrm{~b}$ \\
\hline Least Significant Difference (0.05) & 1.166 & 0.407 \\
Coefficient of variation & 98.39 & 170.04 \\
$R$-square & 0.789 & 0.85
\end{tabular}

Means in a column followed by the same letter are not significantly different (ANOVA and LSD). tropical fruits are grown. These sites were highly dissimilar to the high altitude site of Nyandira site where mostly temperate fruits are grown.

\subsection{Abundance of the major fruit fly pests}

The studies regarding the abundance of fruit flies determined by trapping using two different food baits (the three-component lure and protein bait) show that, when using protein bait, the catches were significantly different (table III); the highest mean weekly catch is that of $B$. invadens and the lowest catch is that of C. cosyra. Similarly, when using the three-component lure, the mean weekly catches of the three species were also significantly different. However, in this case, the highest catch was that of C. rosa, followed by that of B. invadens.

When studying the efficacy of lures in attracting the respective fruit fly species, catches of $B$. invadens by different lures were significantly different, whereby the highest catches were recorded with methyl eugenol, followed by the synthetic food baits (table IV). The catches by synthetic food baits were not statistically different. Similarly, the catches of $C$. rosa by the different lures were significantly different, with trimedlure recording the highest catch

\section{Table IV.}

Efficacy of fruit fly lures in McPhail traps in the Morogoro region, central Tanzania.

\begin{tabular}{lccc}
\hline Lure & \multicolumn{2}{c}{ Mean number of insects per trap per week } \\
& Bactrocera invadens & Ceratitis rosa & $\begin{array}{c}\text { B. invadens, } \\
\text { C. rosa and C. cosyra }\end{array}$ \\
Methyl eugenol & $430.86 \mathrm{a}$ & Not applicable & Not applicable \\
Protein bait & $7.14 \mathrm{~b}$ & $3.6442 \mathrm{~b}$ & $0.37019 \mathrm{a}$ \\
Three-component lure & $0.33 \mathrm{~b}$ & $1.9038 \mathrm{c}$ & $0.01923 \mathrm{~b}$ \\
Cue lure (control) & $0.02 \mathrm{~b}$ & $0.0000 \mathrm{~d}$ & $0.0000 \mathrm{~b}$ \\
Trimedlure & Not applicable & $6.7136 \mathrm{a}$ & Not applicable \\
Least Significant Difference $(0.05)$ & 49.423 & 1.527 & 0.1028 \\
Coefficient of variation & 115.967 & 128.06 & 202.815 \\
$R$-square & 0.908 & 0.883 & 0.692
\end{tabular}

Means in a column followed by the same letter are not significantly different (ANOVA and LSD). 


\section{Table V.}

Incidence of target fruit flies in major fruit species found in the Morogoro region, central Tanzania. Only fruits with more than five positive samples are included.

\begin{tabular}{|c|c|c|c|c|c|c|}
\hline \multirow[t]{2}{*}{ Fruit } & \multicolumn{2}{|c|}{ Bactrocera invadens } & \multicolumn{2}{|c|}{ Ceratitis cosyra } & \multicolumn{2}{|c|}{ Ceratitis rosa } \\
\hline & $\begin{array}{c}\text { Number of } \\
\text { positive samples }\end{array}$ & $\begin{array}{c}\text { Number of } \\
\text { negative samples }\end{array}$ & $\begin{array}{c}\text { Number of } \\
\text { positive samples }\end{array}$ & $\begin{array}{c}\text { Number of } \\
\text { negative samples }\end{array}$ & $\begin{array}{c}\text { Number of } \\
\text { positive samples }\end{array}$ & $\begin{array}{c}\text { Number of } \\
\text { negative samples }\end{array}$ \\
\hline Tropical almond & 75 & 6 & 12 & 69 & & \\
\hline Avocado & 30 & 57 & - & - & 18 & 69 \\
\hline Common guava & 78 & 56 & - & - & - & - \\
\hline Jew plum & 35 & 16 & - & - & - & - \\
\hline Loquat & 26 & 15 & 13 & 109 & - & - \\
\hline Mango & 60 & 62 & & & - & - \\
\hline Sweet orange & 108 & 104 & 6 & 206 & - & - \\
\hline Soursop & 18 & 45 & 32 & 31 & - & - \\
\hline Peach & - & - & & & 11 & 6 \\
\hline Feijoa & - & - & & & 11 & 6 \\
\hline Pearson chi-square & 87.12 & & 98.61 & & 21.4 & \\
\hline Degrees of freedom & 7 & & 3 & & 2 & \\
\hline Probability level & $<0.001$ & & $<0.001$ & & $<0.001$ & \\
\hline
\end{tabular}

compared with the synthetic food baits. However, the catches by synthetic food baits were statistically different, with the protein bait recording higher catches than the threecomponent lure.

\subsection{Incidence of the major fruit fly pests}

Studying the incidence of three fruit fly species in selected fruit species shows that, in most cases, the number of positive samples of $B$. invadens was higher than the number of negative samples, except in soursop, avocado and mango (table V). For C. cosyra, positive samples were less numerous than those of negative samples for all the tested fruit species, except in soursop. The highest difference between the number of positive and negative samples was recorded in mango, followed by tropical almond; in both cases, the number of negative samples exceeded the number of positive samples. Tropical almond, common guava, loquat, sweet orange and mango had less than five positive samples infested by $C$. rosa, and the species was not recorded from jew plum. Where there were less than five positive samples, the fruit species was left out in the analyses. Because of this, the number of fruit species included for analysis with regard to a particular fruit fly species differs.

\section{Discussion}

\subsection{Biodiversity of fruit flies: establishing the key pests in agro-ecosystems}

The first step in formulating an IPM program is establishing the pest complex in a cropping system, since IPM focuses on pest complexes and does not aim at solving a single pest problem. The inventory of fruit fly pests can be useful in conducting pest risk analysis, in the preparation of the list of unwanted fruit fly pests in Tanzania, and in the formulation or strengthening of legislative control measures aimed at protecting the Tanzanian fruit industry against further invasions.

Another important step in formulating an IPM program is the identification of key pest(s) in a pest complex in cropping system(s). Based on the abundance and 
incidence as well as seasonality, control practices against fruit fly pest complexes in orchards should be aimed at B. invadens (the key pest in orchards in low to medium altitudes) and C. rosa (the key pest in high altitude areas). Other pests such as $C$. cosyra and $C$. capitata, whose populations were very low, will be affected by measures targeted against key pests.

\subsection{Fruit fly pest introductions: need for quarantine, surveillance and postharvest treatment}

Two fruit fly invasions, B. invadens and B. latifrons, were detected in 2003 and 2006, respectively. The former is now the key pest causing high losses in the fruit industry. The presence of $B$. latifrons could have an impact on the trade of non-traditional export crops such as chillies. For example, treatments with hot water have been reported to give a good control of $B$. dorsalis [12]. The same techniques can be tried for $B$. invadens and other fruit fly pest species.

\subsection{Abundance of the major fruit fly pests: position of Male Annihilation Techniques (MAT)}

Parapheromones and food baits showed great attraction to the respective fruit fly species, especially methyl eugenol for $B$. invadens and trimedlure for $C$. rosa. Such attractants can be incorporated into IPM programs, especially in low and medium altitude areas, because of the high responsiveness of males of the key pest, $B$. invadens, to methyl eugenol and protein bait. Such measures should be taken over a wide fruit-growing area in order to be effective.

\subsection{Incidence of the major fruit fly pests: strong emphasis of hygiene and sanitation}

The host range of B. invadens is very wide, and includes the non-commercial hosts tropical almonds and marula, which are normally found within the vicinity of commer- cial farms. The incidence of $B$. invadens in the non-commercial hosts is also high. Hygiene and sanitation can be an effective method of reducing fruit fly populations if they take into account the non-commercial but preferred hosts of the key fruit fly pests. These measures will be more effective if reenforced by strong legislative measures.

\subsection{Implementation of an IPM program}

The widespread availability of many noncommercial and wild fruits attacked by different fruit flies within Tanzania and across the borders makes techniques such as the Sterile Insect Technique (SIT), Male Annihilation Techniques (MAT) and biological control difficult to implement, unless done under area-wide control programs. Similar restrictions and conditions are found in other African regions such as western Africa [13]. Obviously, all the programs aiming at the eradication of fruit flies in mainland Tanzania will not be feasible because of the great chances of re-infestation from the neighboring regions or countries. However, such programs can be feasible on the islands like Zanzibar and Mafia.

Any designed IPM program for managing fruit flies should be viewed as a transition from a chemical-dependent control to an ecological model of pest management [14]. Low toxicity bait sprays such as spinosad and natural products such as neem should be researched in the local context on their ability to reduce populations of fruit flies. Studies in India included a neem-based product, azadirachtin, in their IPM program for $B$. dorsalis [12]. The botanical insecticides such as neem are safer to use and are compatible with organic farming.

\section{Conclusion}

At present, Tanzanian farmers can easily adopt a three-component IPM program composed of monitoring fly populations, farm hygiene and sanitation, and bait spray using the low toxicity baits such as spinosad. At the same time, the government should 
enforce quarantine measures and invest in postharvest treatment facilities to help exporters treat their products.

\section{Acknowledgements}

This study was financially supported by the Belgian Development Cooperation through the Framework Program with the Royal Museum for Central Africa (Project F13).

\section{References}

[1] White I.M., Elson-Harris M.M., Fruit flies of economic significance: their identification and bionomics, CAB, Wallingford, UK, 1992, $601 \mathrm{p}$.

[2] Cohen H., Yuval B., Perimeter trapping strategy to reduce Mediterranean fruit fly (Diptera: Tephritidae) damage on different host species in Israel, J. Econ. Entomol. 93 (3) (2000) 721-725.

[3] Jackson C.G., Long J.P., Klungness L.M., Depth of pupation in four species of fruit flies (Diptera: Tephritidae) in sand with and without moisture, J. Econ. Entomol. 91 (1) (1998) 138-142.

[4] Daxl R., Niels V., Carlos K., Rolf L., Hermann W., Integrated pest management, TZ Verl. Ges. mbH, Rossdorf, Germany, 1994, 119 p.

[5] Mwatawala M.W., De Meyer M., Makundi R.H., Maerere A.P., Biodiversity of fruit flies (Diptera, Tephritidae) at orchards in different agro-ecological zones of the Morogoro region, Tanzania, Fruits 61 (5) (2006) 321332.
[6] Anon., Trapping guidelines for area-wide fruit fly programmes, Int. At. Energy Agency, Vienna, Austria, 2003, 47 p.

[7[ Copeland R.S., Wharton R.A., Luke Q., De Meyer M., Indigenous hosts of Ceratitis capitata (Diptera: Tephritidae) in Kenya, Ann. Entomol. Soc. Am. 95 (2002) 672-694.

[8] Ekesi S., Mass rearing technology for Bactrocera invadens and several Ceratitis species in Africa, in: Sugayama R.L., Zucchi R.A., Ovruski S.M., and Sivinski J. (Eds.), Fruit flies of economic importance: from basic to applied knowledge, Proc. 7th Int. Symp. Fruit Flies of Economic Importance, 10-15 Sept. 2006, Salvador, Brazil.

[9] Anon., Crop protection compendium, Commonw. Bur. Agric. Int. (CABI), Wallingford, UK, 2004, CD-Rom.

[10] White I.M., Taxonomy of the Dacina (Diptera: Tephritidae) of Africa and the Middle East, Afr. Entomol. Mem. 2 (2006) 7-156.

[11] Magurran A.E., Ecological diversity and its measurement, Croom Helm, London, UK, $1998,179 \mathrm{p}$.

[12] Verghese A., Tandon P.L., Stonehouse J.M., Economic evaluation of integrated management of the oriental fruit fly Bactrocera dorsalis (Diptera: Tephritidae) in mango in India, Crop Prot. 23 (2004) 61-63.

[13] Vayssières J.-F., Korie S., Coulibaly O., Temple L., Boueyi S.P., The mango tree in central and northern Benin: cultivar inventory, yield assessment, infested stages and loss due to fruit flies (Diptera Tephritidae), Fruits 63 (2008) 335-348.

[14] Aluja M., Future trends in fruit fly management, in: Fruit fly pests: A world assessment of their biology and management, Mc Pheron B.A. (Ed.), St Lucie Press, Florida, USA, 1996, pp. 309-323. 
Concepción de un programa ecológico, basado en una lucha integrada contra los parásitos, con el fin de controlar las moscas de las frutas (Diptera : Tephritidae) en Tanzania.

Resumen - Introducción. Se llevaron a cabo estudios con el objetivo de definir los precedentes antes de la formulación de un programa de lucha integrada contra las moscas de las frutas (Diptera : Tephritidae) en la región de Morogoro, en el centro de Tanzania, de 2004 a 2006. Unos estudios específicos pretendieron determinar la biodiversidad existente entre las poblaciones de moscas de las frutas, así como su incidencia y su abundancia en la región prospectada. Material y métodos. Se colectaron moscas adultas gracias al uso de trampas McPhail cebadas de paraferomonas (eugenol metílico, trimedlure y cuelure) y con atrayentes sintéticos (levadura hidrolizada y señuelo de tres componentes). Asimismo se recuperaron moscas a partir de frutas infestadas incubadas en laboratorio. Se emplearon cuatro localidades y sus regiones colindantes, que representaban tres zonas agroecológicas de la región de Morogoro. Resultados. Se determinaron dos especies mayores de moscas de la fruta basándose en su incidencia en los frutos principales y en su abundancia estacional. La mosca de la fruta invasiva, Bactrocera invadens Drew, Tsuruta y White, es el parásito principal encontrado en los sectores con altitudes baja y media. No obstante, la mosca del Natal, Ceratitis rosa Karsch, es el principal parásito frugívoro en los sectores con altitud alta. Discusión. Un programa de gestión de las moscas de las frutas debería concentrarse en los principales parásitos identificados, tomando en cuenta su multiplicación en los hábitats no-agrícolas. Los temas de un programa de este tipo deberían incluir la técnica de esterilización de los machos (MAT), la legislación, el uso de paraferomonas y de cebos, las medidas sanitarias agrícolas, la cuarentena, la vigilancia y los tratamientos pos-cosecha.

Tanzanía / frutas tropicales / control de insectos / mosca de la fruta / Bactrocera invadens / Ceratitis rosa / identificación / encuestas sobre plagas 